\title{
KINERJA PENGELOLAAN DANA PADA PASAR MODAL INDONESIA
}

\author{
Yuyun Istavirti, SE., MSM ${ }^{1}$, Dr. Ruslan Prijadi, \\ Dr. Andi M. Alfian Parewangi
}

\begin{abstract}
The mutual fund is a fast growing, flexible and sizely attainable product, hence make it as favourable choice for the investors. As in other developing countries, however, the management of the fund invested in mutual fund is done by pointed fund manager. This paper raises and answers the question of how efficient the fund management is. This paper ustilizes the decomposition return model on the monthly data set from 2002-2006 in Indonesia. The model derived, enable us to trace and decompose the management performance into (i) the allocation policy skill, (ii) the security selection skill and (iii) the market timing strategy or the tactical asset allocation abilty.

The model estimation result shows significant management capabilities on allocating the fund into suitable asset class. We record that the best asset allocation policy was on February 2002, June 2004, August 2004 and February 2006. Inline with this, another result shows the negatif contribution of the short term-tactical asset allocation as conformed by several previous studies; Treynor-Mazuy (1996), Wardhani (2003), and Henriksson (1984) among others. There is an exception for February 2006 where a successful market timing strategy contributed an additional $7.34 \%$ return. The security selection strategy is confirmed to have a positive and significant impact on the mutual fund performance. During the observation period, the best security selection strategy was achieved on February, March and July 2002, September 2003, and March, October, and December 2005. For these certain period, the security selection activities gave more than $2 \%$ additional monthly return.
\end{abstract}

1 Yuyun Istavirti adalah lulusan Program Pascasarjan Ilmu Manejemen Universits Indonesia (yuyun.istavirti@gmail.com); Dr. Ruslan Prijadi adalah Ketua PPS Bidang IImu Manajemen Universitas Indonesia; Andi M. Alfian Parewangi adalah staf pengajar FEUI dan konsultan pada Direktorat Riset Ekonomi dan Kebijakan Moneter - Bank Indonesia (andi.alfian@ui.edu). Penulis berterima kasih kepada Prof Dr. I Gusti Ngurah Agung dan Dr. Rofiqoh Rokhim atas komentar dan saran yang diberikan dalam penelitian ini. 
The policy implication is straightforward; a more intensively monitoring on the implementation of the planned asset allocation to give a safer financial investment environment for the investors. This pper also suggest the investment manager to provide a sufficient information about the portfolio's risk profile. Our quantitative description has shown a large varieties both on return and risk across the mutual fund manager showing their varied risk taking behaviour, on which the investor has a right to know.

JEL Classification: H54, G11, G31, O16

Keywords: Mutual fund, asset allocation, security selection, market timing, period specific estimation, financial investment. 


\section{PENDAHULUAN}

Indonesia sebagaimana negara berkembang lainnya, cenderung didominasi oleh pasar uang ketimbang pasar modal. Sejauh ini, dapat dikatakan bahwa peran industri perbankan dalam mengakselerasi sektor riil belum dapat dikatakan memuaskan. Berbagai permasalahan seperti patahnya pass through effect suku bunga dari otorita moneter ke perbankan serta tingginya resiko sektor riil merupakan kendala yang menghambat fungsi utama dari institusi keuangan bank sebagai pool dan intermediator dana.

Menghadapi hal ini pasar modal merupakan salah satu alternatif. Meski pasar modal Indonesia masih tergolong baru, namun merupakan pasar modal tertua di Asia Tenggara dan keempat tertua di Asia setelah Bombay (1830), Hongkong (1871) dan Tokyo (1871)². Dengan jumlah investor yang sedikit, dari segi prestasi pasar modal Indonesia termasuk salah satu diantara 3 negara yang disebut sebagai the fastest growing capital market in Asia (Bapepam-LK,1995). Selama 10 tahun terakhir rata-rata peningkatan indeks tahunan bursa Indonesia mencapai $12,76 \%$, yang merupakan peningkatan tertinggi dibandingkan dengan pergerakan indeks bursa regional lainnya.

Dalam pengelolaan reksadana, dana investor dipercayakan kepada manajer investasi. Ini memunculkan pertanyaan tentang kemampuan manajer investasi untuk mengoptimalkan return dana investasi untuk mencapai tujuan investasi ${ }^{3}$ sesuai dengan yang tercantum dalam prospektus. Secara umum terdapat 3 jenis aktivitas pengelolaan yang dilakukan oleh manajer investasi, pertama, kebijakan alokasi aset yakni keputusan untuk mengalokasikan dana kedalam kelas aset yang ada, kedua, pemilihan sekuritas (stock picking) yakni keputusan untuk memilih instrumen atau produk keuangan dari suatu kelas aset yang sama, dan ketiga, waktu pasar (market timing atau sering dikenal dengan tactical asset allocation) yakni keputusan tentang kapan transaksi dilakukan.

Di Indonesia studi tentang reksa dana menyangkut kemampuan manajer dalam hal market timing dan stock picking dengan memasukkan variabel ekonomi makro pernah dilakukan dengan menggunakan model Henriksson dan Merton (HM). Hasil yang diperoleh menunjukkan bahwa secara keseluruhan manajer investasi masih belum memiliki kemampuan market timing dan faktor ekonomi makro tidak memberikan pengaruh yang berarti terhadap kinerja reksa dana saham (Partawidjaja, 2005).

2 Bapepam-LK Tahun 2004

3 Tujuan investasi yang biasa disebut dalam prospektus adalah menjaga nilai atau melindungi kapital (dana yang diinvestasikan), memperoleh pendapatan tetap, dan membuat pertumbuhan jangka panjang. 
Wardani (2003) dalam studinya mengaplikasikan model Henriksson dan Merton (HM) yang dikombinasikan dengan model Carhart (1997), menemukan bahwa dari 18 reksa dana saham yang diobservasi, hanya satu pengelola yang memiliki menunjukkan kemampuan stock picking yang signifikan. Yati (2000) dengan data harian pada periode 1997-1999 menggunaka model Treynor dan Mazuy (TM), menunjukkan adanya hubungan antara kinerja saham-saham LQ 45 secara individual dengan kemampuan market timing pengelolaan dana. Dia juga memperlihatkan bahwa beta adalah indikator penentu yang pentng dalam market timing sahamsaham di BEJ.

Sedangkan penelitian di luar negeri yang berkaitan dengan reksa dana dalam kaitannya dengan asset allocation, security selection dan market timing telah banyak dilakukan diantaranya oleh Kon (1983) yang menggunakan model pengukuran timing perfomance dari Fama dan risk-adjusted selectivity perfomance-nya Jensen dengan meyertakan Quandt switching-regression model ditambah faktor identitifiability condition dan prosedur diskriminan tambahan yang ia kembangkan sendiri. Kon menemukan bahwa hanya 1 (satu) reksa dana yang memiliki kemampuan pemilihan sekuritas dan market timing yang positif dan signifikan pada level signifikansi 0.05 .

Studi lain yang dilakukan Henriksson (1984) yang menggunakan model HenrikssonMerton, menemukan bahwa hanya 3 dari 116 reksa dana yang memperlihatkan kemampuan timing yang positif signifikan. Dari 3 reksa dana tersebut, keseluruhannya memiliki yang negatif (2 diantaranya bahkan signifikan negatif) yang memperlihatkan inferior stock picking perfomance.

Dari serangkaian telaah studi empiris yang penulis lakukan, sejauh ini penulis belum mendapatkan studi yang menganalisa pengaruh kebijakan alokasi aset, pemilihan sekuritas, dan waktu pasar terhadap kinerja reksa dana saham di Indonesia dalam satu analisis atau model yang terintegrasi. Studi yang ada selama ini menganalisis 3 (tiga) strategi tersebut secara terpisah-pisah. Ini yang merupakan latar belakang dari paper ini yakni apllikasi model yang mampu mengintegrasikan 3 aspek pengelolaan dana secara bersamaan.

Secara eksplisit, paper ini berutujuan untuk menganalisa perkembangan pasar modal di Indonesia melalui pengukuran kemampuan pengelolaan dana investasi oleh para pelaku di pasar modal. Bagian selanjutnya dari paper ini akan menguraikan tinjauan teori dan model teoritis yang menjadi landasaan. Bagian ketiga akan membahas model emprisi dan metodologi yang dipergunakan untuk mengolah data, bagian keempat menyajikan hasil dan analisis sementara kesimpulan akan diberikan pada bagian akhir. 


\section{TEORI}

\section{II.1 Konsep Dasar}

Salah satu produk keuangan yang dipandang sebagai terobosan besar dalam pasar keuangan khususnya pasar modal adalah mutal fund. Per definisi, reksa dana adalah wadah yang dipergunakan untuk menghimpun dana dari masyarakat pemodal untuk selanjutnya diinvestasikan dalam bentuk portofolio efek oleh manajer investasi. Karena sifatnya yang seperti ini, maka potensi partisipatory pelaku ekonomi menjadi lebih besar. Ditambah denngan fleksibilitasnya yang besar, dalam skala agregat reksadana berpotensi menciptakan akumulasi modal yang signifikan.

Terdapat 2 cara mengklasifikasikan reksa dana, pertama berdasarkan sifat operasionalnya dan kedua berdasarkan jenis aset yang terkandung dalam reksa dana itu. Berdasarkan sifat operasionalnya, reksa dana dapat terbagi menjadi 2 yakni reksa dana terbuka (open-end) dengan ciri tidak perlu tercatat di bursa, dapat dijual sepanjang ada peminat, investor dapat menjual kembali produk reksa dana ini ke pengelola dan harga produk ditentukan berdasarkan NAB per saham yang dihitung oleh bank kustodia. Sebaliknya dari ciri itu dikategorikan sebagai reksa dana tertutup (close-end) (Pratomo et al,2002:46). Berdasarkan berdasarkan kategorisasi investasi, saat ini terdapat 6 jenis reksadana, 4 diantaranya yang diobservasi dalam paper ini adalah reksadana pasar uang, reksadana pendapatan tetap, reksadana saham dana dan reksadana campuran.

Dalam pengelolaan dana, manajer investasi dapat mengaplikasikan strategi pertama yakni kebijakan alokasi aset yang merupakan informasi penting bagi setiap investor, terkait dengan toleransi risiko yang mereka miliki. Alokasi aset ini biasanya diartikan sebagai pembentukan bobot kelas aset normal atau bobot kelas aset pasif (Drobetz dan Kohler, 2002). Secara empiris, kebijakan alokasi pasif ini disimpulkan sebagai faktor utama yang menentukan return investasi (Blake et.al.,1998) ${ }^{4}$ dengan peran mencapai 91.5\% (Brinson, Hood dan Beebower, 1986)5 . Konsep utama yang melatarbelakangi lahirnya konsep pengalokasian aset adalah teori portofolio modern ${ }^{6}$ yang diformalkan oleh Harry Markowitz dalam bentuk memasukkan prinsip diversifikasi. Paper seminalnya ini yang mengantarkannya memperoleh hadiah Nobel Ekonomi pada tahun 1990.

\footnotetext{
4 Blake,David,Bruce N.Lehmann,Allan Timmerman (1998),"Asset Allocation Dynamics and Pension Fund Perfomance", Journal of Economics Literature, G11, G23

5 Berdasarkan studi yang dilakukan oleh Brinson, Hood dan Beebower dengan data tahun 1977 sampai dengan tahun 1987, alokasi aset menyumbangkan $91.5 \%$ bagi kinerja investasi, sisanya ditentukan pemilihan sekuritas, market timing dan faktor lainnya.

6 Markowitz, H.M (1952), " Portfolio Selection" The Journal of Finance, March ,Vol.7-1,77-91
} 
Strategi alokasi aset dapat diverifikasi lebih lanjut menjadi 3 tipe (Manurung,2007) ${ }^{7}$, yaitu (i) strategic asset allocation, (ii) tactical asset allocation yang merekomendasikan contrarian trades sesuai dengan kondisi pasar (market timing) yang terjadi, dan (iii) dynamic asset allocation, yang menyerupai aset alokasi strategis namun lebih menekankan pada pengendalian risiko. Pendekatan ini disebut juga sebagai portfolio insurance.

Strategi kedua yang dapat dilakukan manajer investasi adalah pemilihan sekuritas (security selection). 2 buah portofolio dapat memiliki komposisi alokasi yang sama namun dapat berbeda dalam pilihan sekuritas. Tergantung pada kinerja sekuritas yang ada dalam masing-masing portofolio, return kedua portofolio tersebut dapat berbeda.

Kebijakan yang ketiga adalah penentuan kapan harus membeli dan kapan harus menjual instrumen dalam portfolio atau sering disebut strategi waktu pasar (market timing). Rule of thumb implementasi strategi ini adalah buy low sell high. Strategi market timing yang tepat membutuhkan pemahaman atas kondisi dan dinamika pasar. Disini, kemampuan untuk memprediksi variabel-variabel kunci akan menentukan keberhasilan strategi ini.

Informasi investor yang lengkap tentang perilaku dan kinerja manajer investasi, akan memudahkan penilaian apakah manajer investasi mereka telah melakukan smart-investing atau speculative investing. Jika ditelusuri, akar teori untuk alokasi aset dan pemilihan sekuritas adalah sama; kebijakan alokasi merupakan upaya untuk membentuk sebuah frontier yang efisien (efficient frontier) ${ }^{8}$, sementara pemilihan sekuritas sesungguhnya adalah upaya untuk memilih portofolio tertentu di-sepanjang frontier yang telah dipilih sebelumnya.

\section{II.2. Penentuan Benchmark}

Penggunaan tolak ukur (benchmark) dalam pengukuran kinerja reksa dana dimaksudkan untuk membandingkan apakah kinerja reksa dana yang dikelola oleh manajer investasi dapat "mengalahkan" (outperform) pasar atau justru "kalah" (underperform) dari pasar.

Terdapat satu isu yang seringkali menjadi area kontroversi diantara studi-studi tersebut, yakni pemilihan dan penentuan tolok ukur (benchmark). Patokan ini perlu untuk membandingkan kinerja investasi dan mengetahui portofolio mana yang memiliki kinerja lebih baik ditinjau dari besarnya tingkat return dari risiko dibandingkan patokan tersebut (Izakia et al, 1997). Tolak ukur yang digunakan dalam paper ini menggunakan pembanding yang relevan dan umum dipakai oleh pihak reksa dana, seperti Tabel 1.

7 Manurung, Adler. H (2007). "Reksa Dana Investasiku", September, Penerbit Buku Kompas-Jakarta

8 Grafik yang menunjukkan portofolio-portofolio yang memaksimalkan imbal hasil harapan untuk setiap tingkat risiko. 


\section{Tabel IV.1}

\section{Pembanding Kinerja Reksa Dana (Benchmark)}

\begin{tabular}{c|l} 
No. & Jenis Reksa Dana \\
1. & Reksa dana saham \\
2. & Reksa dana pendapatan tetap \\
3. & Reksa dana pasar uang \\
4. & Reksa dana campuran
\end{tabular}

\section{Pembanding}

Indeks Harga Saham Gabungan (IHSG), LQ 45 dan Bisnis 40.

Rata-rata bunga deposito tiga bank (pemerintah dan swasta) untuk periode 12 bulan.

Rata-rata bunga deposito tiga bank (pemerintah dan swasta) untuk periode 3 bulan setelah pajak.

Menggunakan ketiga pembanding diatas

Sumber: Izakia Mahdi, Eko P.Pratomo,Jasper J.Meijerink, 1997:144, Mengukur Kinerja Reksa Dana, Mengapa Harus Reksa Dana? cetakan kedua, Jakarta:Glory Offset Press

Pada bagian berikutnya akan diuraikan konstruksi model empiris yang mengintegrasikan kebijakan alokasi aset, stock picking dan market timing secara bersamaan.

\section{II.3. Model Dekomposisi Return}

Diasumsikan terdapat suatu portofolio $P$ dimana $p \in P$. Masing-masing portofolio terdiri dari $N$ aset dimana $i \in N$ (dalam paper ini terdapat 3 kelas aset). Pada setiap aset $i$ dalam portofolio $p$ tersebut, terdapat $M$ kemungkinan kejadian dimana $j \in M$. Kejadian yang dimaksud adalah seperti kondisi pasar.

Misalkan dalam suatu kurun periode tertentu $t$, terdapat $M=3$ variasi kejadian yakni kondisi pasar yang baik, sedang dan buruk. Probabilita suatu masing-masing kejadian untuk suatu aset $i$ adalah $P_{i j}$. Tentu saja untuk 2 aset yang berbeda, katakan saham 1 dan saham 2 ( $i$ $=1$ dan $i=2$ ), probabilita untuk masing-masing kejadian sangat mungkin berbeda. Dengan spesifikasi seperti ini, maka return yang diharapkan dari sebuah investasi $i$, secara umum dapat dinyatakan dengan rumus sebagai berikut: (Elton et al,2003:46):

$$
\hat{R}_{i}=E\left(R_{i}\right)=\sum_{j=1}^{M} P_{i j} R_{i j}
$$

Dalam hal ini $\hat{R}_{i}=E\left(R_{i}\right)$ adalah tingkat return yang diharapkan dari investasi $i, P_{i j}$ merupakan probabilitas memperoleh return pada investasi $i$ untuk peristiwa $j$, dan $M$ adalah banyaknya peristiwa (event) $j$ yang mungkin terjadi. Rumus tersebut hanya dapat dipergunakan apabila tingkat probabilitas kejadian (probabilitas masing-masing tingkat return) dapat

9 Tolak ukur yang sama juga dikemukakan dalam buku Karvof, Anatoli., (2004). "Guide to Investing in Capital Market" ,PT. Citra Aditya Bakri-Bandung. Pratomo, Eko dan Ubaidillah Nugraha (2005). " Reksa Dana Solusi Perencanaan Investasi di Era Modern", PT. Gramedia Pustaka Utama-Jakarta. 
diperkirakan. Dalam kenyataan umumnya sulit menentukan probabilitas tingkat return, oleh karena itu probabilitas return untuk setiap investasi dianggap sama yaitu: $\frac{1}{M}$ sehingga:

$$
\bar{R}_{i}=\frac{\sum_{j=1}^{M} R_{i j}}{M}
$$

Mengacu pada setting di atas, model dekomposisi total return yang mampu mengadopsi kebijakan alokasi aset, stock picking dan market timing dapat diturunkan dari \h Gambar 1. Model ini dikembangkan dari model dasar yang diajukan oleh Brinson, Hood dan Beebower (1986) dan kemudian diaplikasikan oleh Blake et.al.(1999). Aplikasi model ini untuk Indonesia dilakukan pertama kali oleh Isavirti (2008).

Gambar IV.1. Dekomposisi Total Return

\begin{tabular}{|c|c|c|c|}
\hline & \multicolumn{2}{|c|}{ PEMILIHAN SEKURITAS } \\
\hline & & AKTUAL & PASIF \\
\hline \multirow{4}{*}{ 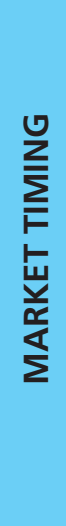 } & & Kuadran-4 & Kuadran-2 \\
\hline & $\frac{3}{\frac{2}{2}}$ & $\begin{array}{l}\text { Return } \\
\text { Aktual }\end{array}$ & $\begin{array}{c}\text { Return dari } \\
\text { Kebijakan Alokasi dan } \\
\text { Market Timing }\end{array}$ \\
\hline & & Kuadran-3 & Kuadran-1 \\
\hline & $\frac{\omega}{\bar{n}}$ & $\begin{array}{c}\text { Return dari } \\
\text { Kebijakan Alokasi dan }\end{array}$ & $\begin{array}{c}\text { Return dari } \\
\text { Kebijakan Alokasi } \\
\text { (Sesuai dengan } \\
\text { benchmark }\end{array}$ \\
\hline
\end{tabular}

Sumber: Brinson, Hood dan Beenbower, 1986

Kerangka ini menampilkan kombinasi dari 2 teknik pengelolaan dana, yakni pemilihan sekuritas dan market timing. Setiap pengelola dana memiliki pilihan apakah secara aktif mengaplikasikan teknik tersebut (kolom/ baris pertama) atau tidak mengaplikasikannya alias pasif (kolom/ baris kedua). Jika pengelola dana tidak melakukan aktifitas pemilihan sekuritas dan market timing, maka return yang dihasilkan semata-mata merefleksikan kebijakan alokasi aset sesuai dengan benchmark. Keuntungan alokasi aset ini tercermin pada Kuadran - 1 .

Retun aktual yang dihasilkan oleh dana yang dikelola, tergambar pada Kuadran - 4 (return aktual). Return aktual ini meliputi semua teknik pengelolaan dana. Jika pengelola dana 
secara aktif melakukan pemilihan sekuritas dan tidak melakukan aktifitas market timing, maka return yang diperoleh merupakan gabungan antara pemilihan sekuritas dan kebijakan alokasi, dan tercermin pada Kuadran - 3. Sebaliknya, ketika pengeola dana secara aktif melakukan market timing namun tidak melakukan pemilihan sekuritas, maka return yang diperoleh sematamata merupakan return dari aktivitas pemilihan sekuritas dan kebijakan alokasi aset. Ini tercermin pada Kuadran - 2.

Dengan demikian, kontribusi masing-masing teknik pengelolaan dana dapat diberikan sebagai:

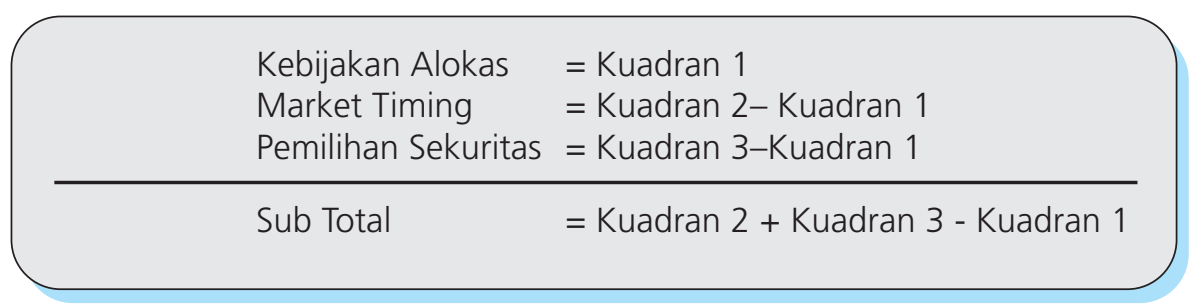

Perlu diperhatikan bahwa selain kebijakan alokasi aset, pemilihan sekuritas dan market timing, terdapat kemungkinan perbedaan total return di atas dengan aktual return (Kuadran 4). Selisih ini merupakan faktor lain seperti perubahan harga aset akibat perubahan ekspektasi masyarakat, dinamika bursa di luar negeri, atau hal-hal sebab lain yang memberikan shock pada pasar keuangan.

Formulasi kerangka dekomposisi ini dapat diberikan secara eksplisit. Asumsikan pengelola dana menghadapi $K$ kelas aset. Jika diasumsikan bahwa pengelola dana tidak melakukan aktifitas pemilihan sekuritas dan market timing, maka satu-satunya yang dilakukan adalah kebijakan alokasi yang merupakan kebijakan pasif. Kebijakan alokasi ini merupakan kebijakan alokasi normal yang idealnya merefleksikan alokasi aset dalam kondisi keseimbangan pasar modal jangka panjang. Alokasi normal untuk setiap kelas aset $k$ pada periode $t$ dinotasikan sebagai $W n_{i t}$. Retun yang diperoleh dari kebijakan alokasi aset semata ini, dinotasikan sebagai $R n_{i t^{*}}$ Dengan asumsi bahwa terdapat $K$ kelas aset, maka total return dari kebijakan alokasi aset pada periode $t$, adalah sebesar: $\sum_{k}^{K} W n_{p k t} \cdot R n_{p k t}$, berkesesuaian dengan Kuadran - 1 pada Gambar IV.1.

Dalam dinamika pasar, retun setiap kelas aset ini dapat berubah-ubah sesuai dengan tarik menarik permintaan dan penawaran pasar. Return aktual setiap kelas aset $k$ pada periode $t$ dinotasikan sebagai $R a_{i t}$. Menyikapi hal tersebut, sangat rasional jika pengelola dana mengantisipasi return aktual yang terjadi sedemikian rupa sehingga komposisi alokasi aktual dalam portofolio akan berubah menjadi $W a_{i t}$. Dari sini kita memperoleh total aktual return 
pada periode $t$ sebesar $\sum_{k}^{K} W a_{p k t} \cdot R a_{p k t}$, berkesuaian dengan Kuadran - 4 pada Gambar IV.1.

Kebijakan market timing memiliki konsekuensi langsung terhadap pengalokasian dana. Ketika seorang pengelola dana memutuskan untuk melepas suatu saham $X$ hari ini dan berencana akan membeli saham yang sama keesokan harinya, maka pada saat itu terjadi rekomposisi alokasi aset dalam portofolio menjadi $W_{i t}$. Dengan demikian, maka return yang dihasilkan murni dari market timing ini adalah perubahan bobot alokasi dikalikan dengan return normal, $\sum_{k}^{K}\left(W a_{p k t}-W n_{p k t}\right) \cdot R n_{p k t}$.

Untuk strategi pemilihan sekuritas, alokasi aset tidak mengalami perubahan sehingga bobot yang dipergunakan tetap bobot alokasi normal $W n_{k t^{*}}$ Namun strategi ini merupakan strategi yang mengantisipasi perubahan return aktual yang terjadi, sehingga net return yang diperoleh dari pemilihan sekuritas adalah sebesar $\sum_{i}^{K} W n_{p k t}\left(R a_{p k t}-R n_{p k t}\right)$.

Dengan kerangka ini kita dapat mengkonstruksi model empiris yang mendekomposisikan total return secara lengkap kedalam komponen-komponennya yakni,

$$
\begin{aligned}
\sum_{k=1}^{K} W a_{p k t} R a_{p k t}= & \sum_{k=1}^{K} W n_{p k t} R n_{p k t}+\sum_{k=1}^{K} W n_{p k t}\left(R a_{p k t}-R n_{p k t}\right) \\
& +\sum_{k=1}^{K}\left(W a_{p i t}-W n_{p i t}\right) R n_{p i t}+\sum_{k=1}^{K}\left(W a_{p k t}-W n_{p k t}\right)\left(R a_{p k t}-R n_{p k t}\right)
\end{aligned}
$$

$W n_{p k t}$ dan $W a_{p k t}$ adalah strategi alokasi normal dan aktual untuk kelas aset $k$ periode $t$ dalam suatu portofolio $p$, sementara dan menunjukkan return normal dan aktual dan untuk kelas aset $k$ pada periode $t$, dalam suatu portofolio $p$. Suku pertama dari model di atas merupakan kontribusi kebijakan alokasi aset terhadap total kinerja, suku kedua merupakan kontribusi pemilihan sekuritas, suku ketiga menunjukkan kontribusi market timing, dan suku keempat merupakan residu yang diasumsikan sangat kecil.

\section{METODOLOGI}

\section{III.1. Data}

Data yang berhasil dikumpulkan untuk penelitian ini adalah data sekunder yang bersumber dari BEJ, Bapepam dan dari pengelola dana. Variabel yang terlibat adalah (i) Net Asset Value $\left(\mathrm{NAV} / \mathrm{unit}^{10}{ }^{10}\right.$, (ii) return harian saham yang terdaftar di BEJ, (iii) tingkat suku bunga SBI (1-

10 Data reinvested Dividend/Cash/Capital Gain Distribution tidak berhasil dikumpulkan karena tidak dipublikasikan. 
Bulan) yang merupakan proxy dari Risk-Free Rate, (iv) rencana alokasi aset masing-masing reksa dana saham yang terdapat dalam prospektusnya, (v) realisasi alokasi aset masing-masing reksa dana saham yang didapatkan dari Bapepam, (vi) tolok ukur (benchmark) return untuk masingmasing kelas aset yakni Indeks Harga Saham Gabungan (IHSG) penutupan untuk kelas aset saham, rata-rata suku bunga deposito 3 bulan bank pemerintah dan swasta untuk kelas aset hutang, dan suku bunga SBI 1 bulan untuk kelas aset deposito.

Alokasi berdasarkan rencana alokasi yang tertuang dalam prospektus, dipergunakan sebagai proksi untuk bobot alokasi aset normal yang mencerminkan alokasi aset dalam kondisi keseimbangan jangka panjang. Ini berbeda dengan Brinson, Hood dan Beebower yang menggunakan rata-rata alokasi aktual dari seluruh periode observasi.

Secara umum, perkembangan return dan alokasi dana oleh 14 pengelola reksadana saham yang diobservasi, tampak pada gambar berikut:

\section{III.2. Teknik Estimasi Panel Period-Specific}

Tersedia banyak pilihan model dalam menganalisa kinerja pasar modal. Beberapa diantaranya adalah CAPM Model, multi-factor model dan conditional multi-factor model, lihat Howe dan Pope (1996), Chalmers et al (1999), Wermers (2000), Pastor dan Stambugh (2001), Kothari dan Warner (2001), Bauer et al. (2002), Kazemi et al,.(2003), Otten dan Bams (2003) dan Patro (2005) untuk kasus pasar modal Amerika Serikat atau Jayadev (1996) untuk reksa dana India, Deaves (2004) untuk reksa dana Kanada, Bangassa (2000) untuk reksa dana Inggris, Christensen untuk reksa dana Denmark, Casarin (2000) untuk reksa dana Italia, dan Annaert et al. (2001) untuk reksa dana di negara-negara Eropa.

Dalam paper ini, penulis mengaplikasikan model data panel dengan teknik estimasi periodspecific. Teknik estimasi ini memungkinkan untuk menganalisa kontribusi ketiga strategi pengelola dana dari waktu ke waktu yang terefleksi pada arah, besaran dan signifikansi dari parameter $\beta_{\mathrm{it}}$. Secara umum, estimasi yang melibatkan series dan cross section dapat diklassfikasikan berdasarkan variasi parameternya.

Model yang paling sederhana adalah ketika seluruh koefisien konstan lintas waktu dan lintas individu. Model dengan parameter yang konstan ini akan mengarah pada (i) model variabel dummy atau model kovarian dan (ii) seemingly unrelated regression (SUR). Model dengan koefisien yang bersifat random akan mengarah pada model error components dan Swamy random coefficient model.

Model panel period-specific ini tergolong dalam varian model Swamy random coefficient 
model (Swamy dan Mehta, 1975, 1977), dalam hal sifat random parameter lintas waktu. Spesifikasi yang paling umum untuk model panel adalah yang memungkinkan parameter bervariasi lintas individu dan waktu,

$$
y_{i t}=\sum_{k=1}^{K} \beta_{k . i t} x_{k . i t}+\vartheta_{i t}
$$

Vektor $\boldsymbol{y}_{\text {it }}$ merupakan serangkaian variabel endogen berukuran $(N x T), \boldsymbol{x}_{k . t t}$ adalah vektor variabel penjelas berukuran ( $N x T X K)$ untuk individu $i \in N$ pada periode $t \in T$ dan $k \in K$ jumlah variabel penjelas. Jika diasumsikan tidak ada perbedaan parameter lintas individu (cross section invariant) maka modelnya menjadi,

$$
y_{i t}=\sum_{k=1}^{K}\left(\overline{\beta_{k}}+\lambda_{k t}\right) x_{k . i t}+e_{i t}
$$

Sebagaimana umumnya permasalahan model time series, model panel period specific ini juga berpotensi mengalami kasus otokorelasi dan kasus heteroscedasticity. Untuk model standar $y=x \beta+\varepsilon$, dengan kovarian $E\left[\varepsilon, \varepsilon^{\prime}\right]=\sigma_{t}^{2} . \Phi$, kasus ini muncul ketika matriks kovarian residual $\Phi$, tidak diagonal dengan elemen diagonal yang merupakan fungsi dari regressor, $\sigma_{t}^{2}=f\left(x_{k i t}\right)$.

Mengatasi kemungkinan ini, maka struktur kovarian parameter random diset secara lebih bebas yakni;

$$
\begin{aligned}
& E\left[\lambda_{t}, \lambda_{s}\right]=\left\{\begin{array}{l}
\Delta ; \forall t=s \\
0 ; \forall t \neq s
\end{array}\right. \\
& E\left[e_{i t}, e_{j s}\right]= \begin{cases}\Delta_{i i} ; \forall i=j, t=s \\
0 & ; \text { otherwise }\end{cases}
\end{aligned}
$$

Setting ini menunjukkan bahwa vektor residual persamaan yang terdiri dari $K$-buah residul, $\boldsymbol{e}_{i t}=\left(e_{1 i t}, e_{2 i t}, \ldots, e_{k i t}\right)$ selain memiliki rata-rata nol $E(\boldsymbol{e})=0$, juga tidak direstriksi untuk diagonal. Keleluasaan yang sama juga diaplikasikan pada efek waktu yang random terhadap slope parameter dengan struktur kovarian $E\left[\lambda \lambda^{\prime}\right]=\Delta$, yang juga tidak harus diagonal. Dalan notasi matriks, model ini dapat diberikan sebagai:

$$
\mathbf{y}_{i}=X_{i} \tilde{\beta}+\widetilde{Z}_{i} \lambda+\mathbf{e}_{i}
$$

Dimensi dari $\boldsymbol{y}_{i}$ dan $\boldsymbol{X}_{i}$ masing-masing $(T \times 1)$ dan $(T \times K)$. Matriks $\lambda^{\prime}=\left(\lambda_{1}^{\prime}, \lambda_{2}^{\prime}, \ldots, \lambda_{T}^{\prime}\right)$ merupakan vektor dengan $T$ buah elemen yang mana elemennya sendiri juga merupakan matriks 
$\lambda_{t}=\left(\lambda_{1 t}, \lambda_{2 t}, \ldots, \lambda_{K t}\right)$ dengan ukuran $(T \times K)$ sehingga secara total ukuran $\lambda^{\prime}$ adalah $(T K x T)$. Residu dari persamaan $\mathbf{e}_{t}=\left(e_{i t}, e_{i t}, \ldots, e_{i t}\right)$ juga merupakan matriks dengan ukuran $(T \times 1)$.

Matriks $\widetilde{\mathbf{Z}}_{i}$ merupakan matirks diagonal dengan elemen $\mathbf{x}_{i t}^{\prime}=\left(x_{i 1}, x_{i 2}, x_{i 3}, \ldots, x_{i T}\right)$ yang juga merupakan matriks dengan ukuran $(N \times T)$. Ukuran total matriks $\widetilde{\mathbf{z}}_{i}$ adalah $(T \times T K)$

$$
\widetilde{Z}_{i}=\left[\begin{array}{ccccc}
x_{i 1}^{\prime} & & & & \\
& x_{i 2}^{\prime} & & & \\
& & \cdot & & \\
& & \cdot & \\
& & & & x_{i T}^{\prime}
\end{array}\right]
$$

Jika diperhitungkan $N$ individu, maka (4 dapat dituliskan kembali sebagai $\mathbf{y}=X \widetilde{\beta}+\tilde{Z} \lambda+\mathbf{e}$, dimana $\boldsymbol{y}, \boldsymbol{X}$, dan $\widetilde{\mathbf{Z}}_{i}$ masing-masing berukuran (NT), (NT $\left.x K\right)$, dan (NT $x$ TK).

Sejauh ini, kita mengasumsikan bahwa hanya time effect yang ada dalam model. Dengan setting seperti ini, maka matriks kovarian dari seluruh komponen random model diberikan sebagai:

$$
\begin{aligned}
& \text { (D) } \quad=E\left[(\tilde{Z} \lambda+\mathbf{e})(\tilde{Z} \lambda+\mathbf{e})^{\prime}=E\left[\tilde{Z}\left(\lambda \lambda^{\prime}\right) \tilde{Z}^{\prime}+\mathbf{e e}^{\prime}\right]\right. \\
& =Z\left(I_{T} \otimes \Delta\right) Z^{\prime}+\sigma_{e}^{2} I_{N T}
\end{aligned}
$$

Bermodalkan ini maka dengan mengaplikasikan teknik estimated generalized least square (EGLS), estimator yang tidak bias dan efisien dapat diperoleh yakni: $\hat{\beta}=\left(\mathbf{X}^{\prime} \boldsymbol{\Phi}^{-1} \mathbf{X}\right)^{-1} \mathbf{X}^{\prime} \boldsymbol{\Phi}^{-1} \mathbf{y}$.

\section{III.3. Model Empiris}

Sebelum estimasi model, terlebih dahulu dilakukan pengujian stasioneritas data dengan panel unit root test. Alternatif pertama pengujian stasioneritas data ini diberikan oleh Levin, Lin dan Chu dan Breitung dengan hipotesa nol ada common unit root. Alternatif lain adalah ImPesaran-Shin, ADF-Fisher dan PP-Fisher dengan hipotesa nol terdapat individual unit root, serta spesifikasi oleh Hadri dengan hipotesa nol tidak ada common unit root.

Berdasarkan model teoritis yang diuraikan sebelumnya model empiris yang diestimasi adalah:

$$
\begin{aligned}
R E T_{i t}=\left(\beta_{1}+\lambda_{1 t}\right) \cdot A L_{i t}+\left(\beta_{2}+\lambda_{2 t}\right) \cdot S S_{i t}+ \\
\left(\beta_{3}+\lambda_{3 t}\right) \cdot M T_{i t}+\left(\beta_{4}+\lambda_{4 t}\right) \cdot \text { Other }_{i t}+\varepsilon_{t}
\end{aligned}
$$


dimana $R E T_{i t^{\prime}} A L_{i t^{\prime}}$ dan $S S_{i t}$ beruturut-turut adalah return investasi yang dihasilkan, keputusan alokasi, pemilihan sekuritas, dan market timing yang dilakukan oleh pengelola dana untuk reksadana i pada periode $t$. Variabel Other $_{i t}$ menangkap faktor lain yang mempengaruhi return diluar 3 kebijakan dan strategi pengelolaan dana. Sebagaimana dijelaskan sebelumnya, parameter random $\lambda_{1}, \lambda_{2 t}, \lambda_{3 t}$ dan $\lambda_{4 t}$ yang menunjukkan time effect dari setiap kebijakan pengelolaan dana yang dilakukan oleh fund manajer, dapat kita peroleh dengan estimasi

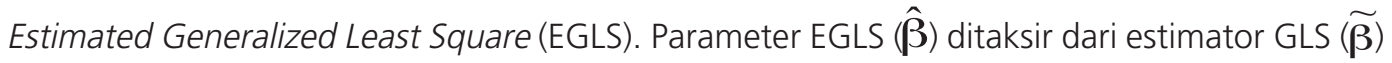
dengan terlebih dahulu menaksir matriks kovarian $\hat{\boldsymbol{\Phi}}$ dari $\boldsymbol{\Phi}$.

Berdasarkan arah, besaran dan signifikansi dari parameter ini, kita dapat mengukur tingkat efisiensi pengelolaan dana pada pasar modal di Indonesia. Dalam taraf aplikasi, mengacu pada model panel period specificyang dijelaskan sebelumya, maka estimasi model empiris ini dilakuan dengan metode kovarian koefisien (coefficient covariant method) Period SUR yang tergolong dalam pendekatan Panel Corrected Standard Error (PCSE), (Beck dan Katz, 1995).

Kovarian koefisien ini robust terhadap perbedaan varian lintas periode meski tidak robust ketika terdapat korelasi contemporenous antar lintas residu persamaan T. Sesungguhnya terdapat asumsi yang lebih tepat dalam menspesifiksi residu seperti mengasumsikan proses residu berjalan mengikuti first order autoregressive namun dalam aplikasi empiris, hal ini dapat menurunkan tingkat akurasi parameter yang diestimasi sehingga tidak penulis ikuti (Doran dan Griffiths, 1983 dalam Judge et.al., 1985).

\section{HASIL DAN ANALISIS}

Inspeksi awal data menunjukkan bahwa semua variabel stasioner pada, baik menggunakan Levin-Lin-Chu, Breitung, Im-Pesaran-Shin maupun dengan Hadri. Pengujian unit root atas residual model juga menunjukkan hal yang sama. Ini menguatkan bahwa tidak ada masalah dalam spesifikasi dan kemungkinan spurious.

Pengujian atas normalitas error tidak dilakukan sebab jumlah series data yang dipergunakan sebanyak 60 periode dengan 14 cross section. Jumlah observasi ini 2 kali lebih besar dari yang umumnya dipersyaratkan yakni 30 periode. Uji multikolinearitas juga tidak dilakukan sebab data merupakan data panel yang merupakan salah satu cara mengatasi kasus multikolinearitas selain transformasi (Gujarati, 1986). Selain itu tanda-tanda adanya kasus multikolinearitas yang ditandai dengan nilai $R^{2}$ yang besar dan $t$-statistik yang umumnya tidak signifikan, tidak ditemukan pada setiap hasil estimasi model. 
Tabel IV.2

Kontribusi Strategi Pengelolaan Dana terhadap Return Bulanan Reksadana

\begin{tabular}{|c|c|c|c|c|c|c|}
\hline Periode & Kebijakan Alokasi & Alokasi Aset & t Taktis & Stock Picking & \multicolumn{2}{|c|}{ Lainnya } \\
\hline Feb-02 & 0,84 & 4,76 & & 2,06 * & 0,79 & \\
\hline Mar-02 & 1,95 * & $-1,74$ & * & 2,06 * & $-1,85$ & $* *$ \\
\hline Apr-02 & 1,80 * & $-1,32$ & * & 1,80 * & $-0,90$ & $* *$ \\
\hline May-02 & 2,43 * & $-2,76$ & * & 1,72 * & $-1,10$ & $* * *$ \\
\hline Jun-02 & 1,68 * & $-0,64$ & * & 1,60 * & 0,08 & \\
\hline Jul-02 & 1,94 * & 0,15 & & 2,13 * & 0,93 & $* *$ \\
\hline Aug-02 & 1,76 * & $-0,23$ & & 1,84 * & 0,40 & \\
\hline Sep-02 & 1,76 * & $-1,52$ & ** & 1,77 * & $-0,18$ & \\
\hline Oct-02 & 1,81 * & $-1,12$ & * & 1,81 * & $-0,35$ & \\
\hline Nov-02 & 1,82 * & $-0,86$ & * & 1,83 * & 0,13 & \\
\hline Dec-02 & 1,69 * & $-0,73$ & * & $1,60 *$ & $-0,10$ & \\
\hline Jan-03 & 1,69 * & $-0,83$ & * & 1,56 * & $-0,38$ & ** \\
\hline Feb-03 & 1,74 * & $-1,00$ & * & 1,72 * & 0,02 & \\
\hline Mar-03 & $-7,04$ & 15,25 & & 1,80 * & $-1,52$ & * \\
\hline Apr-03 & 1,82 * & $-1,48$ & * & 1,78 * & $-1,22$ & * \\
\hline May-03 & 1,68 * & $-0,83$ & * & 1,55 * & $-0,27$ & * \\
\hline Jun-03 & 1,70 * & $-0,88$ & * & 1,65 * & $-0,72$ & * \\
\hline Jul-03 & 1,97 * & $-2,78$ & * & 1,83 * & $-1,58$ & * \\
\hline Aug-03 & 1,64 * & $-0,55$ & & $1,55 *$ & $-0,09$ & \\
\hline Sep-03 & 1,95 * & $-1,43$ & * & 2,24 * & $-0,46$ & \\
\hline Oct-03 & 1,79 * & $-1,27$ & * & 1,72 * & $-0,75$ & ** \\
\hline Nov-03 & 1,83 * & $-1,35$ & * & 1,78 * & $-0,99$ & * \\
\hline Dec-03 & 1,75 * & $-1,06$ & * & 1,66 * & $-0,62$ & * \\
\hline Jan-04 & 1,74 * & $-1,04$ & * & $1,61 *$ & $-0,47$ & * \\
\hline Feb-04 & 1,80 * & $-1,22$ & * & 1,84 * & $-1,25$ & * \\
\hline Mar-04 & 1,85 * & $-1,44$ & * & 1,67 * & $-0,86$ & * \\
\hline Apr-04 & 1,73 * & $-0,96$ & * & $1,65 *$ & 0,18 & \\
\hline May-04 & 1,67 * & $-0,56$ & * & 1,58 * & 0,23 & * \\
\hline Jun-04 & 2,37 * & $-1,00$ & & 1,83 * & $-1,26$ & * \\
\hline Jul-04 & $1,75^{*}$ & $-1,18$ & * & 1,69 * & $-0,30$ & ** \\
\hline Aug-04 & 3,17 * & $-2,16$ & * & 1,61 * & $-0,61$ & * \\
\hline Sep-04 & 1,80 * & $-1,38$ & * & 1,75 * & $-1,19$ & * \\
\hline Oct-04 & 1,78 * & $-1,25$ & * & 1,74 * & $-0,35$ & \\
\hline Nov-04 & 1,74 * & $-1,02$ & * & 1,77 * & $-1,05$ & * \\
\hline Dec-04 & 1,35 * & 0,72 & & 1,71 * & $-0,91$ & * \\
\hline Jan-05 & 1,96 * & $-3,08$ & * & 1,62 * & $-0,34$ & * \\
\hline Feb-05 & 1,83 * & $-2,13$ & * & 1,70 * & $-0,62$ & * \\
\hline Mar-05 & 1,89 * & $-0,56$ & & 2,04 * & $-2,21$ & \\
\hline Apr-05 & 1,68 * & $-0,68$ & ** & 1,58 * & 0,09 & \\
\hline May-05 & 1,68 * & $-0,86$ & * & 1,43 * & 0,09 & \\
\hline Jun-05 & 1,71 * & $-0,91$ & * & $1,64 *$ & $-0,67$ & * \\
\hline Jul-05 & 1,75 * & $-1,16$ & * & 1,68 * & $-0,82$ & * \\
\hline Aug-05 & 1,80 * & $-1,31$ & * & 1,65 * & $-0,74$ & * \\
\hline Sep-05 & 1,99 * & $-0,98$ & & 1,87 * & 1,39 & \\
\hline Oct-05 & 1,96 * & $-1,94$ & * & $2,01 *$ & $-2,15$ & * \\
\hline Nov-05 & 1,78 * & $-1,23$ & * & $1,83 *$ & $-1,48$ & * \\
\hline Dec-05 & $1,92 *$ & $-1,47$ & * & 2,07 * & $-0,70$ & $* * *$ \\
\hline Jan-06 & 1,81 * & $-1,38$ & * & 1,87 * & $-1,19$ & * \\
\hline Feb-06 & $3,88 * * *$ & $-2,35$ & * & $1,79 *$ & $-1,47$ & * \\
\hline Mar-06 & 1,72 * & $-0,97$ & * & $1,73 *$ & $-1,04$ & * \\
\hline Apr-06 & 1,79 * & $-1,16$ & * & $1,80 *$ & $-0,48$ & \\
\hline May-06 & 1,73 * & $-0,99$ & * & 1,73 * & $-1,02$ & * \\
\hline Jun-06 & 1,88 * & $-1,63$ & * & 1,82 * & $-1,17$ & $* *$ \\
\hline Jul-06 & $1,75^{*}$ & $-1,16$ & * & $1,57 *$ & $-0,29$ & \\
\hline Aug-06 & 1,71 * & $-0,95$ & * & 1,70 * & $-0,94$ & * \\
\hline Sep-06 & 1,74 * & $-0,95$ & $* * *$ & 1,73 * & $-0,62$ & \\
\hline Oct-06 & 1,71 * & $-1,14$ & ** & 1,59 * & $-0,55$ & \\
\hline Nov-06 & 1,90 * & $-1,49$ & ** & 1,87 * & $-1,13$ & \\
\hline Dec-06 & 1,63 * & 1,05 & & 1,86 * & 2,34 & $* * *$ \\
\hline
\end{tabular}

*) Signifikan pada $\left.\alpha=1 \%,,{ }^{*}\right)$ pada $5 \%$ dan ***) pada $10 \%$.

Estimasi model dekomposisi period specific. Variable dependent: Total Return, Method: Pooled EGLS (Period weights). R-squared $=0.999905$, Adjusted R-squared $=0.999867$, S.E. of regression $=0.007401$, DW stat $=2.004910$. 
Hasil estimasi divisualisasikan pada Gambar IV.2 dan Tabel IV.2. Secara umum model empiris tergolong baik dengan Adjusted $R^{2}=0.999$, standar error $=0.007401$, dan statistik Durbin Watson = 2.0049 yang menunjukkan model terbebas dari serial korelasi.

Sepanjang periode observasi, hasil estimasi menunjukkan signifikansi peran positif strategi alokasi aset dan pemilihan sekuritas terhadap kinerja reksa dana di Indonesia. Untuk tahun 2002, kontribusi strategi alokasi aset terbesar terjadi pada bulan Mei 2002 dengan koefisien 2,43 . Besaran koefisien ini menunjukkan bahwa kebijakan alokasi pasif ini mampu memberikan return yang senantiasa lebih besar dari return pasar, dan untuk bulan Mei 2002 ini, kebijakan alokasi pasif tersebut memberikan tambahan return 2,43\% per bulan diatas return pasar. Pada bulan Mei 2002 ini NAB mencapai angka tertinggi sepanjang tahun dengan rata-rata 1488,2. Setelah itu, NAB mengalami penurunan hingga 1211,23 pada akhir tahun.

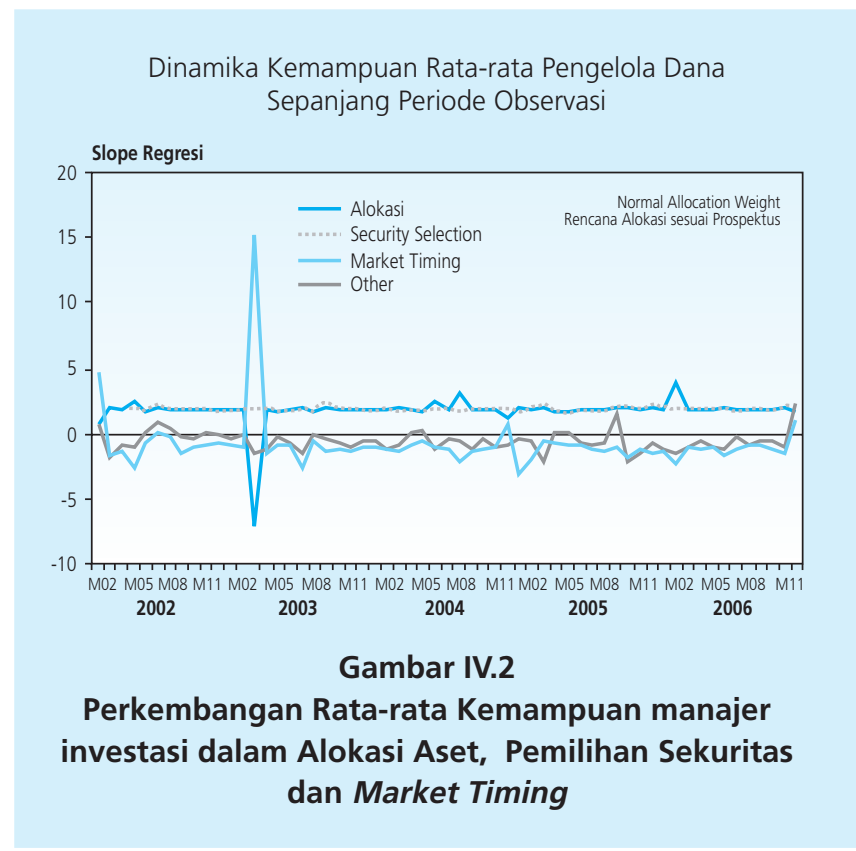

Hasil estimasi panel dengan alokasi sesuai prospektus sebagai proksi bobot alokasi normal.

Secara umum, perkembangan kinerja reksa dana saham di Indonesia sampai tahun 2002 relatif buruk. Rata-rata tingkat return masing-masing reksa dana saham pada tahun ini bernilai negatif kecuali 3 reksa dana Si Dana Saham, Nikko Saham Nusantara dan Arjuna dari 14 reksadana yang diobservasi. Salah satu penyebabnya adalah lebih banyak investor yang tertarik untuk menaruh dana-nya pada jenis reksa dana pendapatan tetap.

Ketertarikan penempatan dana pada reksa dana pendapatan tetap ini didorong oleh sekuritisasi obligasi rekap (securitization of recap bond) yakni obligasi negara yang dipak dan 
dijual sebagai reksa dana. Hal ini juga ditunjang oleh tren penurunan suku bunga SBI. Kelesuan pasar saham secara umum tercermin dari peningkatan total nilai perdagangan saham di BEJ yang sangat kecil, Rp 7.063 miliar, menyusul penurunan frekuensi perdagangan per November 2002 hanya 1.763 kali sedangkan tahun sebelumnya 1.814 kali (Bapepam, 2002).

\begin{tabular}{|c|c|c|c|c|}
\hline \multicolumn{5}{|c|}{$\begin{array}{c}\text { Tabel IV.3 } \\
\text { NAB dan Rata-rata Alokasi Kelas Aset, Tahun } 2002\end{array}$} \\
\hline Periode & $\begin{array}{l}\text { Nilai Aktiva } \\
\text { Bersih }\end{array}$ & $\begin{array}{c}\text { Kelas Aset } \\
\text { Uang }\end{array}$ & $\begin{array}{c}\text { Kelas Aset } \\
\text { Hutang }\end{array}$ & $\begin{array}{c}\text { Kelas Aset } \\
\text { Ekuitas }\end{array}$ \\
\hline Januari & $1.255,75$ & $18,7 \%$ & $1,9 \%$ & $79,4 \%$ \\
\hline Februari & $1.257,96$ & $25,4 \%$ & $7,8 \%$ & $66,8 \%$ \\
\hline Maret & $1.312,51$ & $16,4 \%$ & $2,4 \%$ & $81,2 \%$ \\
\hline April & $1.474,64$ & $16,8 \%$ & $3,1 \%$ & $80,1 \%$ \\
\hline Mei & $1.488,22$ & $13,4 \%$ & $2,4 \%$ & $84,3 \%$ \\
\hline Juni & $1.424,98$ & $18,7 \%$ & $1,9 \%$ & $79,4 \%$ \\
\hline Juli & $1.337,11$ & $18,3 \%$ & $18,9 \%$ & $62,8 \%$ \\
\hline Agustus & $1.298,05$ & $31,2 \%$ & $24,5 \%$ & $44,3 \%$ \\
\hline September & $1.198,86$ & $16,4 \%$ & $19,7 \%$ & $63,9 \%$ \\
\hline Oktober & $1.077,55$ & $22,2 \%$ & $1,1 \%$ & $76,7 \%$ \\
\hline November & $1.127,50$ & $21,4 \%$ & $18,4 \%$ & $60,2 \%$ \\
\hline Desember & $1.211,23$ & $19,4 \%$ & $1,0 \%$ & $79,6 \%$ \\
\hline
\end{tabular}

Menghadapi hal ini, reaksi utama dari para pengelola dana adalah melakukan realokasi dana sebagaimana diilustrasikan pada Gambar IV.3. Terdapat 2 titik waktu yakni bulan September dan November 2002 yang mana alokasi atas ekuitas mengalami titik terendah. Upaya realokasi jangka pendek atau tactical asset allocation yang disesuikan dengan kondisi pasar ini tidak membantu bahkan memberikan kontribusi negatif terhadap return. Berdasaran hasil estimasi panel period-specific, koefisien alokasi aset taktis adalah sebesar minus 1,52 (September 2002) dan minus 0,86 (November 2002). Bahkan pada bulan Mei 2002 ketika NAB mengalami titik tertinggi dan kebijakan alokasi pasif memberikan marginal return terbesar (2,43\% per bulan), kebijakan alokasi aset taktis (market timing) justru memberikan pengurangan return terbesar, minus 2,76\% per bulan (signifikan pada). Satu-satunya kontribusi kebijakan market timing yang positif hanya terjadi pada bulan Juni 2002 dengan koefisien yang sangat kecil $(0,15)$, itupun secara statistik tidak signifikan. Kegagalan alokasi aktif para menajer investasi reksadana saham ini menunjukkan bahwa kebijakan alokasi pasif yang tertuang dalam prospektus masih merupakan kebijakan alokasi yang superior dan memberikan return lebih dibandingkan return benchmark.

Berbeda dengan upaya realokasi dana, upaya pemilihan sekuritas (stock picking) selama tahun 2002 ini mampu memberikan kontribusi positif terhadap total return, terutama pada 

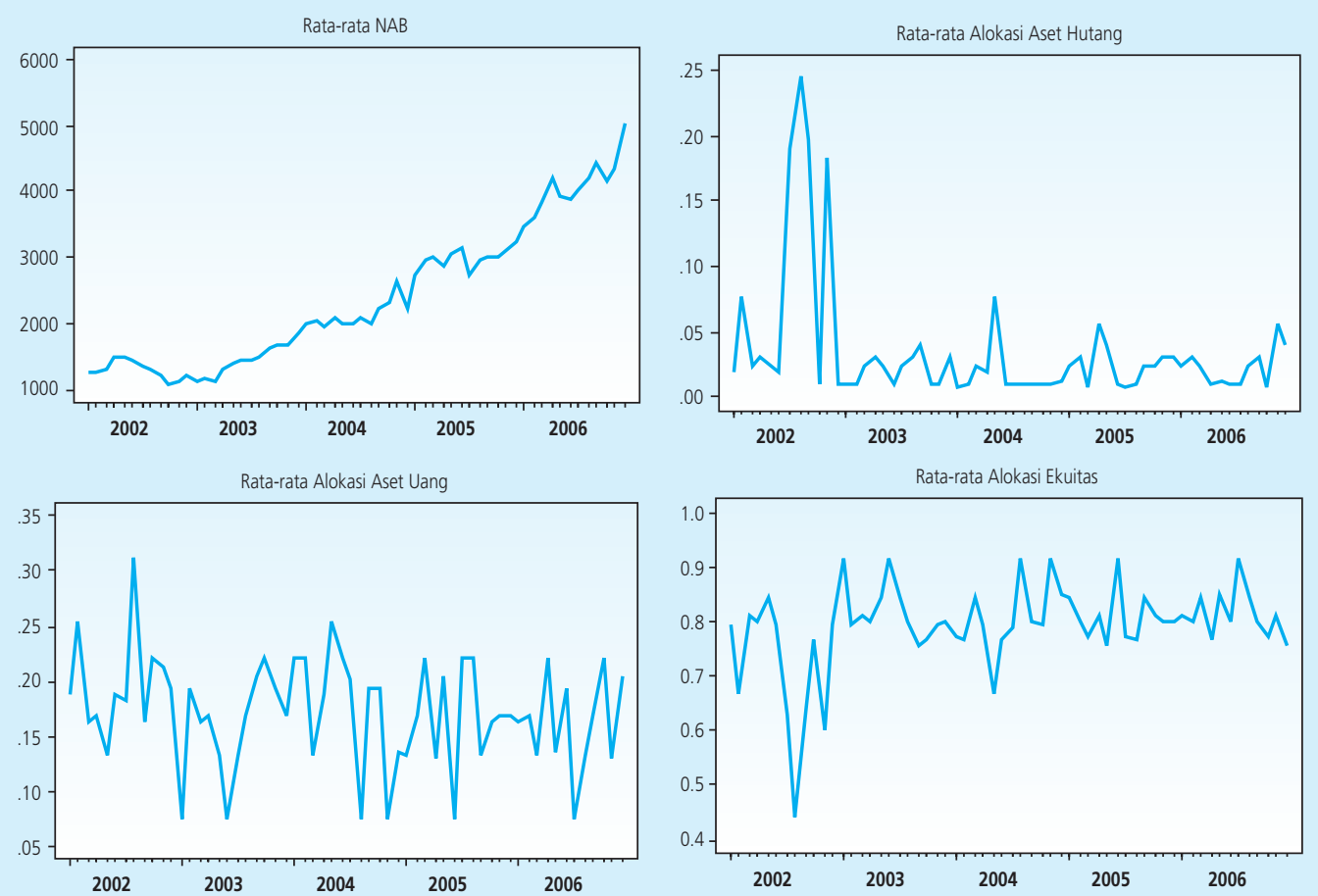

\section{Gambar IV.3}

Perkembangan NAB dan Kebijakan Alokasi Aktual

Sumber: Bapepam, diolah.

semester pertama. Khususnya pada bulan Juli 2002 para pengelola reksadana mampu memilih efek yang memberikan return lebih diatas return rata-rata pasar. Hasil estimasi juga menunjukkan bahwa kemampuan pemilihan sekuritas ini senantiasa positif sepanjang periode observasi.

Pada periode 2003, meski NAB reksadana saham secara rata-rata masih lebih rendah dari tahun 2002, reksadana saham mulai kembali mengalami peningkatan. Alokasi dana untuk ekuitas naik $11 \%$ menjadi $91 \%$ yang merupakan pengalihan dari kelas aset uang. Salah satu faktor pedorong utama menggeliatnya pasar modal pada tahun ini adalah kecenderungan inflasi yang semakin menurun dengan volatilitas yang rendah. Tercatat inflasi sebesar 8,76\% (y.o.y) pada awal tahun dan terus menurun hingga 5,09\% pada akhir tahun 2003. Penurunan inflasi domestik ini berkebalikan dengan laju inflasi dunia. Pada kelompok negara maju, laju inflasi meningkat menjadi menjadi 1,9\% dari 1,5\% pada tahun 2002

Pada sisi lain, nilai tukar Rupiah mengalami apresiasi terhadap Dollar dan stabil pada level rata-rata Rp8.577,13. Faktor ini mendorong suku bunga terus menurun sepanjang tahun 


\begin{tabular}{|c|c|c|c|c|}
\hline \multicolumn{5}{|c|}{$\begin{array}{c}\text { Tabel IV.4 } \\
\text { NAB dan Rata-rata Alokasi atas Kelas Aset, Tahun } 2003\end{array}$} \\
\hline Periode & $\begin{array}{l}\text { Nilai Aktiva } \\
\text { Bersih }\end{array}$ & $\begin{array}{c}\text { Kelas Aset } \\
\text { Uang }\end{array}$ & $\begin{array}{c}\text { Kelas Aset } \\
\text { Hutang }\end{array}$ & $\begin{array}{c}\text { Kelas Aset } \\
\text { Ekuitas }\end{array}$ \\
\hline Januari & 1117,83 & $8 \%$ & $1 \%$ & $91 \%$ \\
\hline Februari & 1149,30 & $19 \%$ & $1 \%$ & $80 \%$ \\
\hline Maret & 1139,86 & $16 \%$ & $2 \%$ & $81 \%$ \\
\hline April & 1287,80 & $17 \%$ & $3 \%$ & $80 \%$ \\
\hline Mei & 1406,07 & $13 \%$ & $2 \%$ & $84 \%$ \\
\hline Juni & 1440,31 & $8 \%$ & $1 \%$ & $91 \%$ \\
\hline Juli & 1449,04 & $13 \%$ & $2 \%$ & $84 \%$ \\
\hline Agustus & 1477,72 & $17 \%$ & $3 \%$ & $80 \%$ \\
\hline September & 1617,44 & $20 \%$ & $4 \%$ & $75 \%$ \\
\hline Oktober & 1699,80 & $22 \%$ & $1 \%$ & $77 \%$ \\
\hline November & 1683,13 & $19 \%$ & $1 \%$ & $80 \%$ \\
\hline Desember & 1856,15 & $17 \%$ & $3 \%$ & $80 \%$ \\
\hline
\end{tabular}

seiring menurunnya tingkat suku bunga SBI 1 bulan sebesar 462 bps dibandingkan tahun sebelumnya, yang diantisipasi oleh pelaku bursa dengan pengalokasian dana dari pasar uang ke pasar modal.

Meski tahun 2003 ini dapat dikategorikan sebagai tahun yang stabil, reaksi dari pengelola reksa dana saham bervariasi dari bulan ke bulan sepanjang tahun ini, sebagaimana terlihat dalam Tabel IV.4. Berdasarkan hasil estimasi, kebijakan alokasi taktis yang dilakukan oleh para pengelola dana yang disesuaikan dengan kondisi pasar secara statistik justru memberikan tambahan negatif bagi return. Kesalahan terbesar dalam hal pembobotan kelas aset terjadi pada bulan Juli 2003 yang memberikan marginal return negatif sebesar minus 2,78\%. Ini berarti setiap pergerakan alokasi sebesar 1\% yang menyimpang dari rencana alokasi awal, secara rata-rata menurunkan return rekasadana saham sebesar minus 2,78\% per bulan.

Dalam hal strategi pememilihan sekuritas, para pengelola dana berhasil memilih sekuritas yang memberikan return diatas rata-rata return pasar sepanjang tahun 2003. Pada bulan September 2003, kemampuan stock picking dalam memberikan marginal return mencapai 2,4\% yang tertinggi selang periode 2002- 2006 .

Maret 2003 merupakan pengecualian. Pada bulan ini, koefisien marginal untuk pemilihan sekuritas sebesar 1,8\%, yang menunjukkan performa baik para manajer investasi dalam memilih sekuritas yang menguntungkan. Pada sisi lain, kebijakan alokasi pasif yang direncanakan sesuai dengan prospektus, justru memberikan return yang jauh dibawah return benchmark. Hal ini ditunjukkan dengan koefisien marginal return sebesar minus 7,04\%. Strategi alokasi taktis yang merupakan keputusan realokasi dana lintas kelas aset oleh manajer investasi, justru membuahkan tambahan return sebesar $15,25 \%$ per bulan. 
Fenomena bulan Maret 2003 ini perlu digarisbawahi; yakni secara statistik 2 strategi terakhir (alokasi pasif dan alokasi taktis) tidak signifikan. Ini dapat diinterpretasikan bahwa kebijakan alokasi ini tidak berlaku umum untuk seluruh pengelola dana yang diobservasi dalam penelitian ini. Pada bulan Maret 2003 ini, variasi return reksa dana sangat tinggi (1,62), atau 28 kali lebih tinggi dibanding rata-rata variasi 11 bulan lainnya pada tahun yang sama.

Pemicu fenomena bursa saham pada bulan Maret 2003 ini adalah mencuatnya kekhawatiran akan percahnya perang di Irak, menyusul berakhirnya masa tenggak waktu yang diberikan Amerika kepada Irak untuk melucuti senjatanya. Dalam skala global, antisipasi telah dilakukan oleh berbagai pihak antara lain Jepang dan Amerika yang membuat kesepakatan untuk mengambil langkah bersama ketika perang mengancam bursa (Fukuda, konferensi pers 19 Maret 2003) sementara Taiwan menurunkan band pergerakan harga saham yang tadinya + 7\% dalam sehari dan bahkan membuka kemungkinan untuk menghentikan transaksi bursa sama sekali. Selain itu Taiwan juga berencana mengaktifkan Dana Stabilitas Nasional (NSF). Di Korea Selatan, otoritas moneter menegaskan langkah intervensi dalam bentuk tax break dan injeksi likuiditas manakala diperlukan untuk meredam gejolak bursa.

Ketika pasar sedang menunggu, reaksi dari 14 pengelola dana yang diobservasi ini beragam sehingga memberikan hasil yang sangat variatif, lihat Lampiran 1. Penelusuran individual menunjukkan reksa dana Nikko, BIG Nusantara, Master Dinamis, Mawar dan Bahana mencatat return yang fantastis pada Maret 2003 ini yakni 459\%, 141\%, 88\%,66\% dan 27,88\%. Pada sisi lain, reksa dana yang terpuruk adalah Si Dana Saham, Panin Dana Maksima, Phinisi dan Schroder masing-masing dengan return minus 66\%, minus 47\%, minus $40 \%$ dan minus $37 \%$. Hal ini dapat diilustrasikan pada perkembangan NAB dari 14 reksadana saham yang diobservasi pada Gambar IV.4.

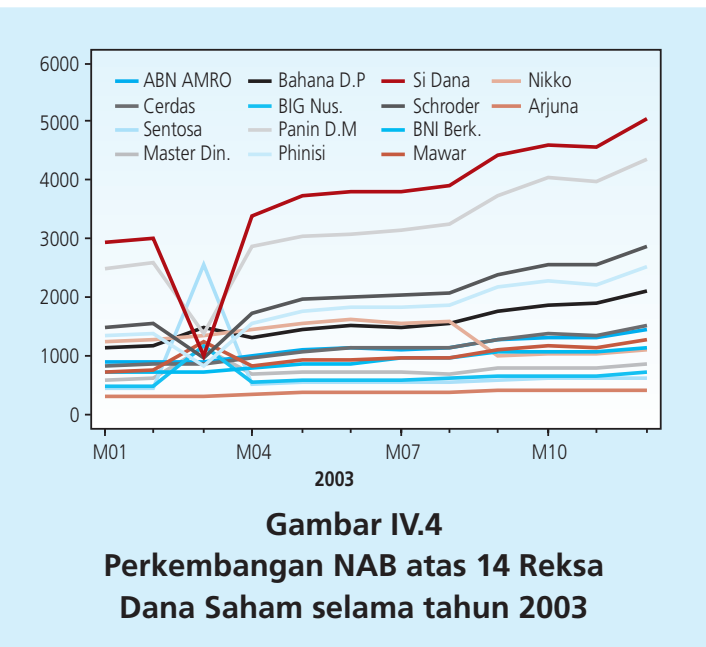


Tahun 2004 merupakan tahap perkembangan lebih lanjut reksa dana di Indonesia. Dengan situasi perekonomian yang relatif stabil, rata-rata return reksa dana saham di Indonesia tercatat 34\% relatif lebih tinggi dibandingkan dengan rata-rata return di Asia seperti di Filipina, 27, 1\% (Lipper Company). Lonjakan NAB untuk reksa dana secara umum di Indonesia sangat signifikan yakni Rp104,04 trilyun dibandingkan dengan tahun 2003 sebesar Rp69,47 trilyun. Meskipun demikian 14 reksa dana saham yang diobservasi dalam penelitian ini hanya menunjukkan tingkat return rata-rata 3,7\%. Rata-rata return tertinggi sepanjang tahun 2004 ini dibukukan oleh BIG Nusantara sebesar 21,6\% sementara yang terburuk adalah Danareksa Mawar dengan return rata-rata minus $1,6 \%$.

Variasi alokasi aset taktis lintas 14 reksa dana yang diobservasi cukup besar. Kecuali untuk beberapa pengeloa dana, secara umum hasil estimasi menunjukkan strategi alokasi aset taktis tidak mampu meningkatkan return, bahkan memberikan marginal return yang negatif yang menunjukkan pembobotan kelas aset yang salah arah. Pada bulan Agustus 2004, kesalahan pembobotan ini memberikan penurunan marginal atas return sebesar minus 2,16\%. Pada saat yang bersamaan, kebijakan alokasi pasif secara signifikan memberikan tambahan return sebesar 3,17\%.

Tahun 2005 ditandai dengan pengetatan likuiditas otoritas moneter melalui peningkatan suku bunga SBI dan mengakibatkan crash pada pasar modal. Kondisi ini kemudian mendorong sebagian pemilik reksa dana melakukan redemption sehingga mengakibatkan aset industri reksa dana diawal tahun sebesar Rp 108,223 triliun anjlok 74.49\% menjadi Rp 27,589 diakhir tahun 2005. Dampak dari kebijakan ini mengalami puncaknya pada bulan Maret dengan beralihnya alokasi dana ke pasar uang menjadi 22\% dari 13\% pada awal tahun. Reaksi individual dalam bentuk kebijakan alokasi taktis dapat dilihat dalam Lampiran IV.1.

Pada akhir Agustus 2005, harga minyak dunia merangkak naik dan mencapai level tertinggi pada US\$ 71 per barel. Ini memicu kenaikan harga BBM yang pada akhirnya memicu inflasi. Menghadapi shock eksternal ini, pengelola dana merealokasi dana dalam portofolio mereka, dan berupaya memilih sekuritas yang berpotensi memberikan keuntungan lebih besar, dalam hal ini pasar uang dana aset riil. Saat ini harga minyak mentah per Mei 2008 telah menyentuh US\$143 per barel, atau 200\% dibandingkan Agustus 2005. Meski tidak masuk dalam periode observasi, namun pola perilaku investor menghadapi kenaikan harga minyak mentah yang memicu inflasi, relatif sama.

Perbandingan inflasi yang kontras dapat terlihat pada angka inflasi $1.42 \%$ per Januari 2005, dan di akhir Oktober mencapai 15.65\% (Bank Indonesia, 2005). Meski inflasi berdampak secara menyeluruh terhadap semua produk pasar uang dan pasar modal, namun reaksi dari jenis produk tersebut terhadap perubahan inflasi berbeda-beda, tergantung pada tingkat elastisitas pasar atas inflasi. Peningkatan inflasi ini menurunkan tingkat suku bunga riil yang 
merupakan biaya dalam memegang uang. Dari sudut pandang investor, ini merupakan penurunan daya tarik produk pasar uang, dan pada periode ini rata-rata tingkat realokasi untuk pasar uang menurunkan sebesar 3\%.

Bagi produk pasar modal terutama obligasi, inflasi yang terjadi selang tahun 2005 ini akan meningkatkan penawaran obligasi akibat menurunnya biaya relatif pendanaan perusahaan melalui penerbitan obligasi. Pada saat yang bersamaan inflasi secara relatif menurunkan return obligasi dibandingkan dengan aset riil, dari sudut pandang investor. Hal ini memicu penurunan permintaan obligasi.

Hasil estimasi menunjukkan bahwa upaya realokasi dana yang dilakukan oleh para manajer investor pada tahun 2005 ini, tidak berhasil. Berdasarkan hasil estimasi hanya upaya pemilihan sekuritas yang mampu memberikan marginal return yang positif. Pada akhir 2005, strategi pemilihan sekuritas mampu memberikan marginal return sebesar 2,97\%.

\section{KESIMPULAN DAN SARAN}

Penelitian ini menunjukkan kontribusi positif yang signifikan atas kebijakan alokasi aset pasif yang telah ditentukan dan tertuang dalam prospektus masing-masing reksadana. Temuan ini selaras dengan berbagai penelitian sebelumnya tentang peran besar kebijakan alokasi dalam menentukan return investasi reksadana. Hasil penelitian juga menunjukkan peran positif dan signifikan dari strategi pemilihan sekuritas terhadap kinerja reksa dana saham yang diobservasi. Ini menunjukkan kemampuan para pengelola untuk melihat perkembangan pasar menyangkut sekuritas yang mampu memberikan return yang lebih baik dari return pasar.

Pada sisi lain, strategi alokasi aset taktis yang disesuaikan dengan kondisi pasar (market timing) justru memberikan marginal return yang negatif. Secara rata-rata, kesalahan manajer investasi dalam hal strategi market timing yang terbesar, terjadi pada Januari 2005, Juli 2003, Mei 2002 dan Februari 2006, masing-masing dengan koefisien sebesar minus 3.0773, minus 2.7850, minus 2.7636 dan minus 2.3539. Ini menunjukkan stretegi pembobotan kelas aset oleh manajer investasi pada bulan-bulan ini, salah dalam arah pengalokasian.

Mengingat alokasi aset memiliki pengaruh yang positif dan signifikan terhadap kinerja reksa dana, maka sebaiknya Bapepam melakukan monitoring yang intensif terhadap pelaksanaan kebijakan alokasi aset yang telah ditetapkan oleh masing-masing reksa dana sebagaimana tercantum di dalam prospektusnya. Hal ini diharapkan dapat memicu para manajer investasi untuk melakukan kebijakan investasi yang konsisten sehingga para investor merasa terlindungi.

Hasil penelitian ini menyarankan perlunya penyediaan informasi yang memadai untuk investor mengenai risiko oleh pengelola aset (asset management). Memang setelah crash tahun 
2005 prospektus yang terbit telah mencantumkan risiko tetapi risiko yang tercantum hanya informasi umum yang berkaitan dengan pengelolaan investasi. Saran ini didasarkan pada identifikasi kuantitatif atas dinamika return dan risiko yang cukup bervariasi lintas reksa dana yang menunjukkan tingkat pengambilan risiko yang bervariasi lintas pengelola.

Negatifnya kontribusi strategi market timing yang ditunjukkan dalam penelitian ini, secara eksplisit memberikan saran kepada para pengelola dana untuk memperpanjang horizon waktu yang dipertimbangkan dalam optimalisasi kinerja pengelolaan dana mereka. Dengan kata lain, penulis menyarankan agar para pengelola dana tidak terlalu bereaksi atas volatilitas pasar jangka pendek.

Sebaliknya, kontribusi positif dari strategi security selection secara eksplisit memberikan saran agar para pengelola lebih mencermati kondisi fundamental dari para perusahaan yang me-listing sahamnya pada bursa. Ini menggiring pada saran lebih lanjut agar dilakukan penyempurnaan informasi tentang kondisi fundamental perusahaan baik oleh pengelola dana maupuan oleh lembaga yang memiliki otoritas atas pasar modal termasuk Bapepam dan pengelola bursa. Informasi ini juga melingkupi informasi tentang fundametal makro perekonomian seperti ekonomi dan politik, peraturan, nilai tukar, risiko likuiditas.

Mengingat kemungkinan konflik interst yang potensial terjadi, penulis menyarankan kepada otoritas moneter untuk mendukung adanya lembaga yang independen untuk melakukan analisa kinerja para pengelola dana. Dalam jangka panjang, penulis meyakini hal ini akan mendukung perkembangan reksa dana yang lebih baik.

Untuk penelitian lebih lanjut, paper ini perlu dikembangkan dalam bentuk aplikasi teknik estimasi yang memiliki selain kelebihan teknik estimasi panel, juga berkemampuan untuk mengatasi masalah-masalah yang sering terjadi pada data runtun waktu seperti masalah serial korelasi. Salah satu contoh teknik seperti ini adalah panel GARCH. Hal ini penting untuk mempertajam analisis terhadap reksa dana yang ada di Indonesia.

Mengingat keterbatasan data sebagaimana yang penulis alami, maka perlu dilakukan penelitian lebih lanjut dengan cakupan data yang lebih baik. Baik dalam hal jumlah jenis reksa dana, dan juga dalam hal panjang series serta frekuensi yang lebih tinggi misalnya harian.

Penelitian ini telah berhasil mendekomposisikan dan mengatribusikan total return kedalam 3 komponennya; alokasi aset, pemilihan sekuritas dan waktu pasar. Namun demikian, penelitian ini tidak secara khusus menguraikan tentang penyebab dinamika dan variasi dari 3 komponen tersebut sepanjang waktu. Ini juga membuka ruang penelitian lebih lanjut yang turut memperhitungkan faktor-faktor perilaku, persepsi dan interprestasi terhadap kondisi pasar, serta variabel kebijakan. 


\section{Daftar Pustaka}

Bapepam, Statistik Pasar Modal, Minggu ke V Desember 2003

Black,David,Bruce N.Lehmann,Allan Timmerman (1998), "Asset Allocation Dynamics and Pension

Fund Perfomance", Journal of Economics Literature, G11, G23

Brinson,G.P.,L.,Hood L.R dan Beebower G.L.,(1986)," Determinants Portofolio Perfomance", Financial Analyst Journal,(July/August),39-48.

Brinson, G.P.,L.,Singer B.D dan Beebower G.L.,(1991), " Determinants Portofolio Perfomance II: An Update", Financial Analyst Journal,(May/June), 40-48.

Carhart, Mark M (1997). On Persistence in Mutual Fund Perfomance, The Journal of Finance, Vol II No.1, p.57-82.

Drobetz,Wolfgang, Friederike Kohler (2002)." The Contribution of Asset Allocation Policy to

Portfolio Perfomance",Working Paper,No.2/02, Basel: Department of Finance, University of Basel.

Elton, Edwin J., Martin J.Gruber, Stephen J. Brown, William Goetzmann, 2003, Modern Portofolio Theory and Investments Analysis, USA: John Wiley \& Sons, Inc.

Gujarati N, Damodar, (2003). Basic Econometrics, Fourth Edition, New York: McGraw-Hill Companies, Inc.

Howe, Thomas S. And Ralph A. Pope, (1996). Equity Mutual Fund Historical Perfomance Ratings As Predictors of Future

Istavirti, Yuyun, (2008), Pengaruh Strategi Asset Allocation, Security Selection dan Market Timing

terhadap Kinerja Reksa Dana Saham di Indonesia, tesis pada Program Pascasarjana IImu Manajemen Universitas Indonesia.

Judge, et.al, (1985), The Theory and Practice of Econometrics, John Wiley \& Sons, Singapore. Kothari, S.P. and Jerold B.Warner (2001). Evaluating Mutual Fund Perfomance, Journal of Finance,

Vol. LVI No.5.

Mahdi, Izakia, Eko P. Pratomo dan Jasper J. Mejerink, 2002, Mengukur Kinerja Reksa Dana, Mengapa harus Reksa Dana?, p. 141-157.

Manurung, Adler H., (2007). Reksa Dana Investasiku. Penerbit Buku Kompas -Jakarta Markowitz, H.M (1952), "Portfolio Selection" The Journal of Finance, March ,Vol.7-1,77-91. Partawidjaja, Djumyati (2005), " Pengukuran Kinerja Reksa Dana Saham Berdasarkan Market Timing dan Stock Selection Serta Fakor Ekonomi Makro yang Mempengaruhinya", Tesis S-

2 yang tidak dipublikasikan, Pascasarjana IImu Manajemen Universitas Indonesia.

Pratomo,Eko.P. dan Ubaidillah Nugraha (2002). Reksa Dana Solusi Perencanaan Investasi di Era 
Modern, PT. Gramedia Pustaka Utama-Jakarta.

Roy D. Henriksson, R.C. Merton, "On Market Timing and Investment Perfomance: Statistical Procedure for Evaluating Forcast Skills,"Journal Business 54, October 1981.

Swamy dan Mehta, (1975), "Bayesian and Non Bayesian Analysis of Switching Regressions ande of Random Coefficient Regression Models", Journal of the American Statistical Association, 70, 593-602.

(1977), "Estimation of Linear Models with Time and Cross-Sectionally Varying Coefficients", Journal of the American Statistical Association, 72, 80-898

Treynor, Jack L. and K. Mazuy (1996). Can Mutual Funds Outguess the Market?., Harvard Business Review, p. 131-136.

Wardani, Ratna (2003), Analisis Faktor-Faktor Determinasi Kinerja Reksa Dana Saham di Indonesia Periode 1998-2001, Tesis S-2 yang tidak dipublikasikan, Pascasarjana IImu Manajemen Universitas Indonesia. 

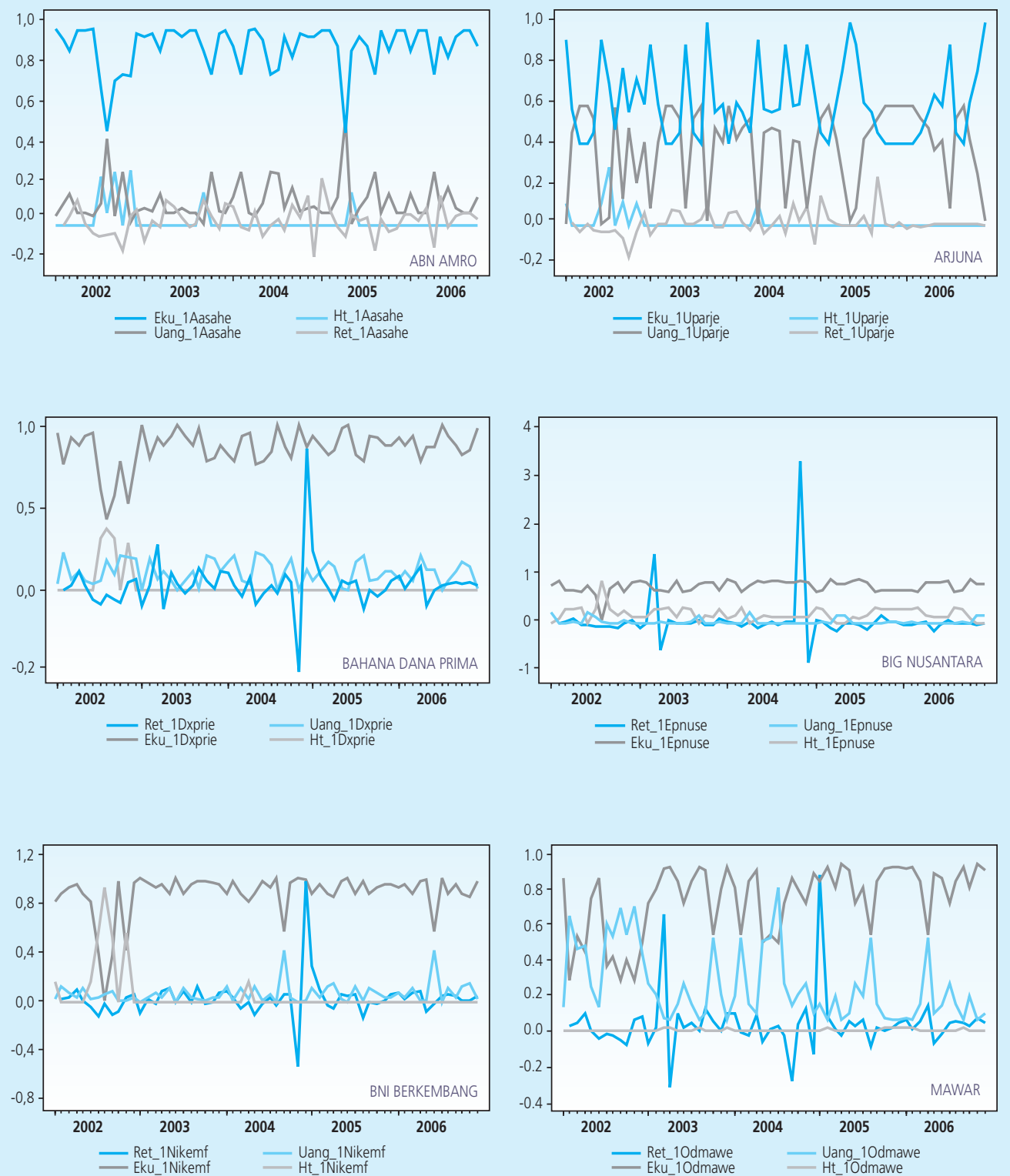

Grafik Lampiran IV.1

Return dan Alokasi Dana atas 14 Reksadana Saham, 2002-2006 

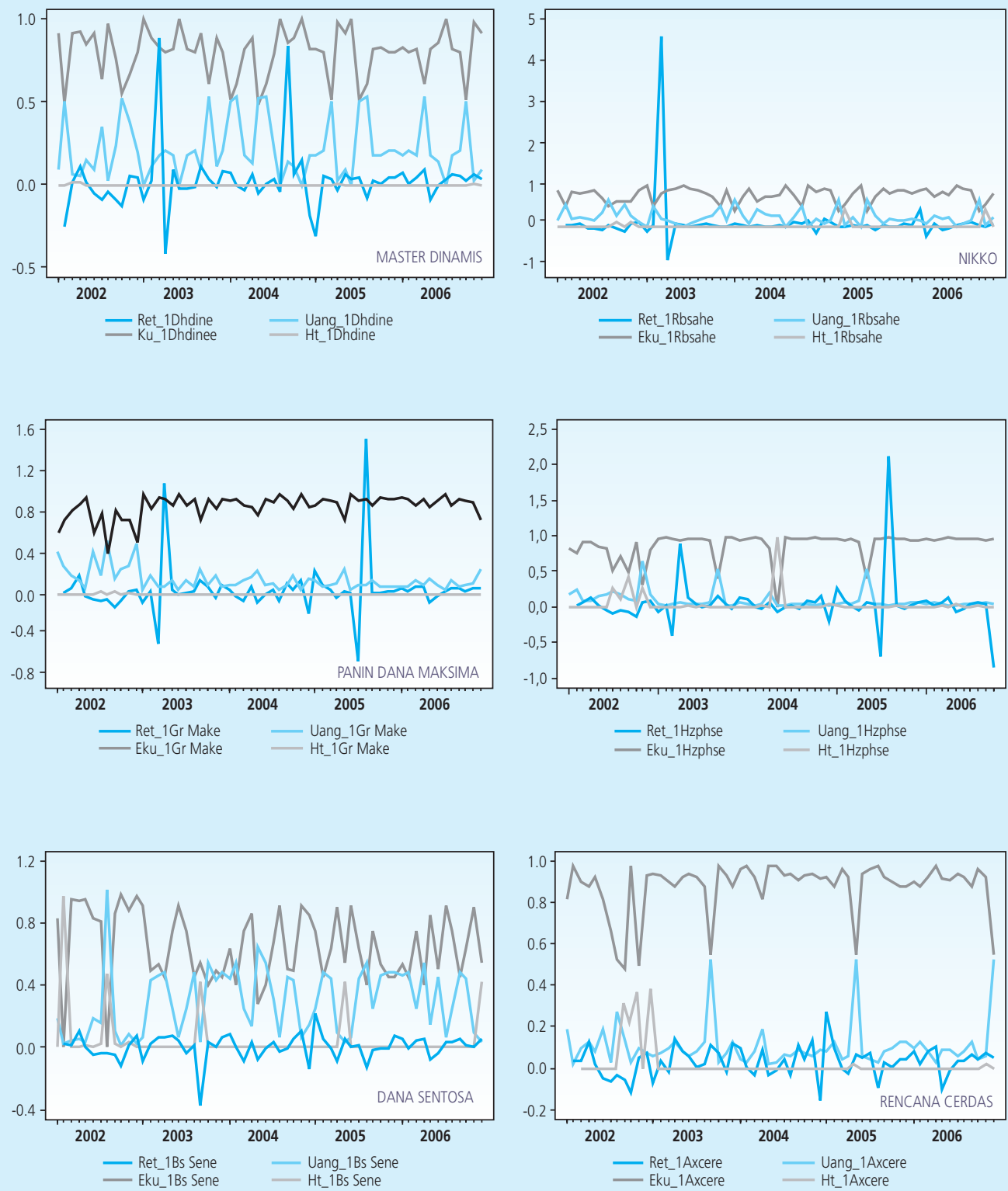

Sumber: Bapepam, diolah. 

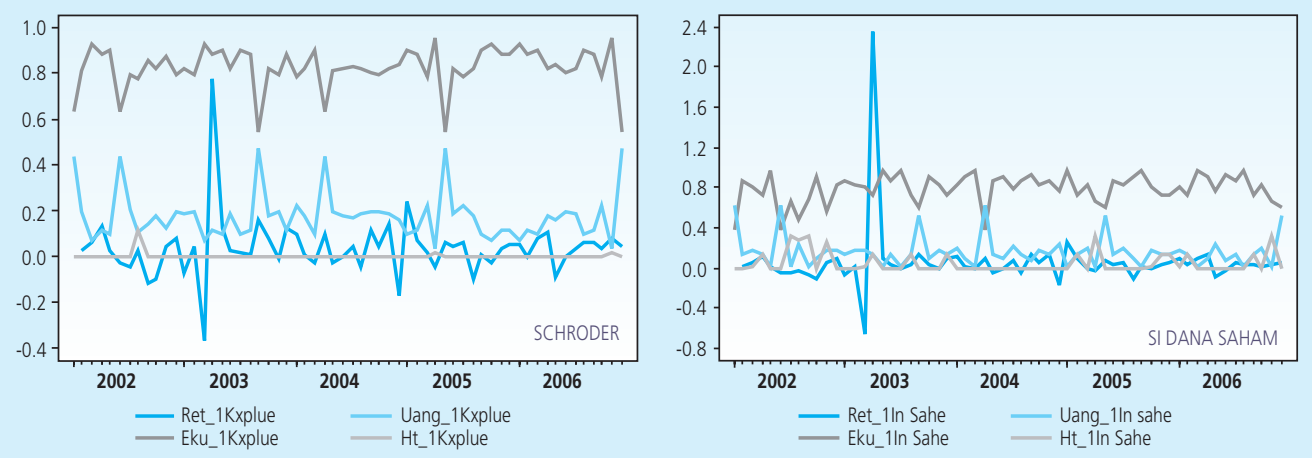

\section{Grafik Lampiran IV.1}

Return dan Alokasi Dana atas 14 Reksadana Saham, 2002-2006 (Lanjutan) 
Pertumbuhan IHK

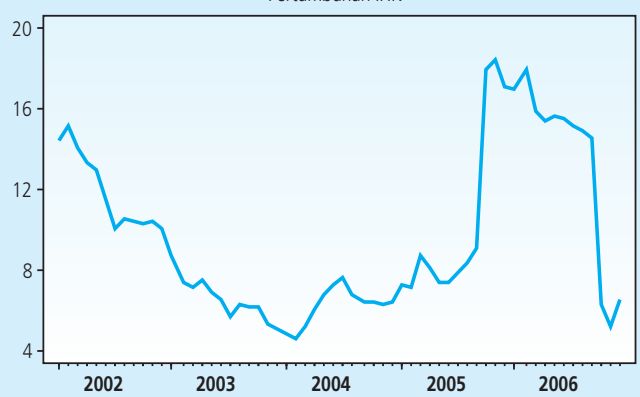

Suku Bunga Diskonto (\% pa.)

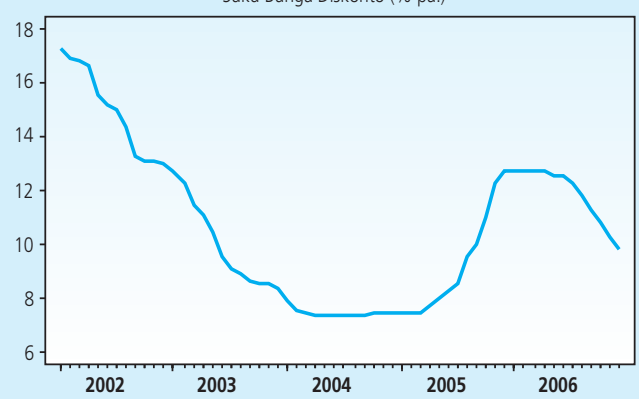

Call Money Rate (\% pa.)

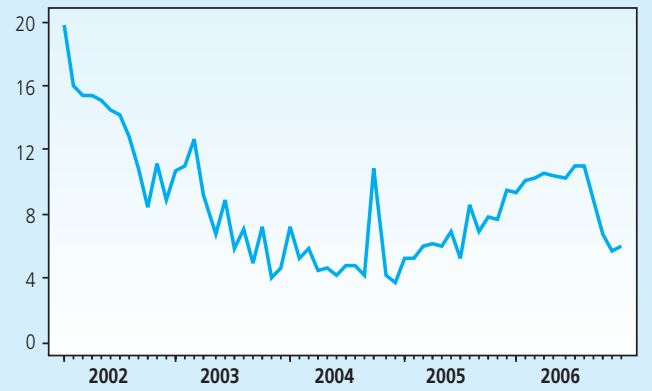

Harga Minyak Mentah (US\$ per Barrel)

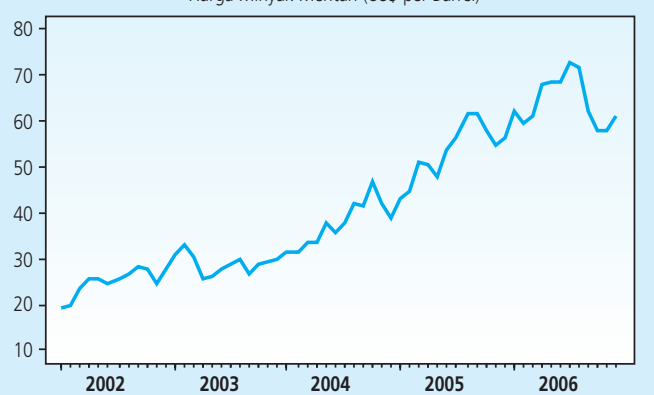

Kurs Rata-rata Rupiah terhadap US\$

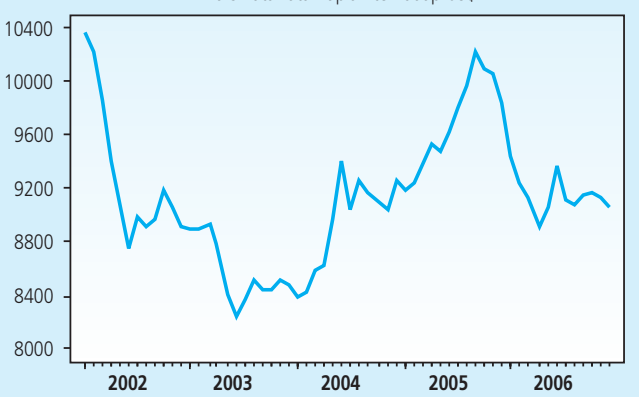

Sumber: International Financial Statistic, IMF (2007). 
halaman ini sengaja dikosongkan 